\title{
Erratum: The impact of a Biblical Fatherhood Programme for faith communities in the Christiana district: A reflective and community engagement strategy
}

Author:

Fazel E. Freeks ${ }^{1}$ (D)

\section{Affiliation:}

${ }^{1}$ Unit for Reformed Theology and the Development of the South African Society, Faculty of Theology, North-West University, Potchefstroom, South Africa

Corresponding author:

Fazel Freeks,

10589686@nwu.ac.za

Date:

Published: 23 Nov. 2021

How to cite this article: Freeks, F.E., 2021, 'Erratum: The impact of a Biblical Fatherhood Programme for faith communities in the Christiana district: A reflective and community engagement strategy', In die Skriflig 55(3), a2794. https://doi.org/ 10.4102/ids.v55i3.2794

\section{Copyright:}

(C) 2021. The Authors. Licensee: AOSIS. This work

is licensed under the Creative Commons Attribution License.
In the version of this article initially published, Freeks, F.E., 2021, 'The impact of a Biblical Fatherhood Programme for faith communities in the Christiana district: A reflective and community engagement strategy', In die Skriflig 55(1), a2680. https://doi.org/10.4102/ids. v55i1.2680, the article issue number was given incorrectly. The correct issue number should be number 3 instead of number 1 .

This correction does not alter the study's findings of significance or overall interpretation of the study results. The publisher apologises for any inconvenience caused. 


\section{The impact of a Biblical Fatherhood Programme for faith communities in the Christiana district: A reflective and community engagement strategy}

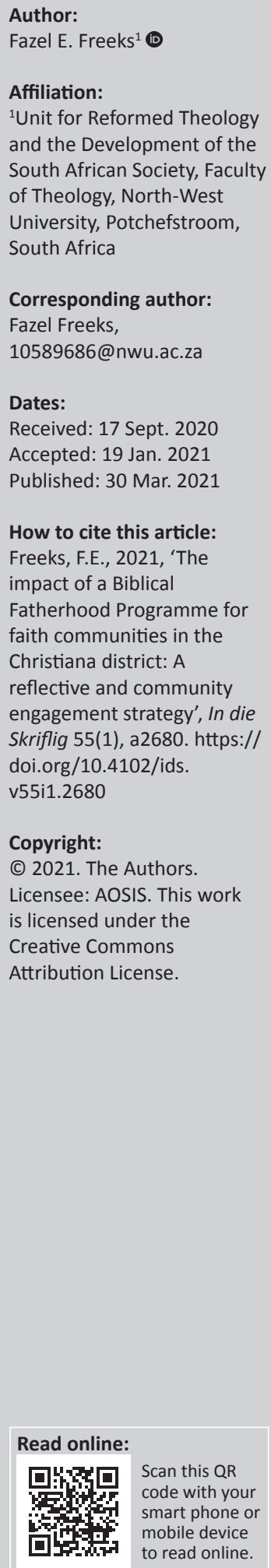

The farming communities in the Christiana district with a population of close to 21000 residents struggled with issues including poverty, unemployment, financial problems, alcoholism, occultism and Satanism and family issues such as father absence, fatherlessness and single parenting. An intervention that included training and equipping of fathers, who were farm workers from the local faith community, was necessary and crucial. Farm workers (faith communities) responded to the need for a biblical fatherhood programme. Human fatherhood should be recognised and given serious consideration because it gave an anticipation of who God the Father is. If human fatherhood did not exist, then all truth and knowledge about God the Father would be void and insignificant. Fatherhood today is an element of broken families and perhaps the most threatened element in the world. The aim of this article was to lessen the social issue of father absence through the implementation of the Biblical Fatherhood Programme. The programme has a biblical nature to solve social ills within communities. The programme was developed from a practical-theological study on fatherhood, with the primary reason to train and equip participants with fatherhood knowledge. This article presents a reflective and community engagement strategy, based on the author's reflection of items that arose when a biblical fatherhood programme was presented to farm workers in the Christiana district of South Africa. Reflection as a methodology enabled researchers and practitioners to theorise from their own practice, improving and developing their work. Reflection was a turning back onto 'a self' where the researcher was the observer of the scenario. Reflection was also a significant and mental activity for researchers to use in their work with participants. The results and this article presented the reflective, rather than empirical findings of the programme implementation. The training intervention was presented in a narrative form and based on research about the essence of fatherhood. This was conceptualised from biblical truth and perspective. Participants showed immense interest in the programme and the Bible. Their theological views concerning the Bible for answers were crucial to their problems and situations. Participants' spiritual life was pivotal to enjoy healthy relationships with God.

Contribution: The programme contributed monumentally to the lives of participants. It was impossible for participants to live their lives without the Bible. The Bible is not just an authoritative source of teaching, but it speaks of human fatherhood and serves as a guideline to enunciate the care of God the Father.

Keywords: Biblical Fatherhood Programme; fatherhood; father absence; faith communities; reflective; community engagement.

\section{Rationale}

In the context of this article, community engagement is the approach to help society with communal problems and challenges. Holland and Malone (2019:1) defined community engagement as the process of involving communities in decision-making, implementation and collaboration. Polat and Yildiz (2019:71) indicated that community engagement is an integral part of the planning and designing in developing communities. Through community engagement, faith communities can be reached through intervention, community programmes and projects. The term faith communities refer to people who belong to a particular church or a particular religious group. These people share a particular set of religious beliefs or religious faith. There are varying levels of commitment in any faith community. 
The need for collaboration between the North-West University and faith communities is crucial, especially in rural areas like the Christiana district. Rural communities are often underserved because of a variety of challenges (Baldwin \& Poje 2020:16). Mashau's (2019:6) article stated that the role of faith communities should be emphasised as important because there should be a home for the homeless, a voice for the voiceless, and protectors for those who are marginalised in society. In so doing, they need to work to avoid conflict amongst community members (Moon 2019:99). In addition, faith communities are being recognised as important leaders in communities because they address the problematic factors that shape religious life and communities (Hardison-Moody \& Yao 2019:363). Furthermore, faith communities should become an enabling environment that makes it possible for communities to acquire knowledge (Chifeche \& Dreyer 2019:4).

In the context of this article, biblical knowledge should be an ideal approach to the fatherhood concept. A community engagement programme such as the Biblical Fatherhood Training and Equipping Programme from the North-West University Faculty of Theology emphasises the concept of fatherhood according to biblical truth and guidelines. The concept of fatherhood can be derived from the Bible, and this notion provides exceptional guidelines that attest to the distinctiveness of God as Father. In terms of the human fatherhood, the value of an earthly father within a household system is significant. The apical nobility God can grant on a man is to call him a father (Munroe 2001). 'The fathers have eaten a sour grape and the children's teeth are set on edge' (Jr 31:29). This verse symbolises the dominion of the father as the key authority of the family. However, there have been progressive changes in the activity and architecture of the family and remarkable shifts in the authority of the father (Oliker 2011). The words 'The fathers have eaten ...', appeared also in Ezekiel 18:2 where it is mentioned as a proverb. Men complained that they are being punished and that they suffered for the sins of their previous generation. The same words are attached to the second commandment in Exodus 20:5 and these fathers found in their generation a plea for their own recklessness.

Jeremiah and Ezekiel felt that these specific words clothed with a divine authority. Each man is responsible for his own acts. The 'eaten of the sour grapes, his teeth shall be set on edge' is an emendation of the proverbial saying. For no guilt, they shall pay the forfeit of their fathers' sins.

\section{Background}

Christiana is a district with residents of at least 21000 and mostly agricultural workers. It is located on the banks of the Vaal River in the North West province of South Africa. Christiana is on the N12 between Bloemhof and Warrenton, on the way to Kimberley in the Northern Cape. This town is the administrative centre of Lekwa-Teemane Local Municipality (Wikipedia n.d.). The Christiana is a marketplace where people congregate, connect and experience a way of life together and where Jesus Christ can invade through the Bible (Wyngaard 2015:413).

The farming communities in the Christiana District struggle with issues such as broken families, father absenteeism, fatherlessness, unemployment and violence (Freeks 2018). The researcher has observed that with support from the North-West University and the Faculty of Theology, communities such as Christiana have been enriched through a Biblical fatherhood training and equipping programme, irrespective of the challenges.

This programme trains and equips faith communities with biblical knowledge about the Fatherhood of God and human fatherhood. Furthermore, the programme is an ideal buffer against the challenges of father absence in faith communities being faced their daily lives.

The Biblical Fatherhood Training and Equipping Programme has been implemented in this district since 2011.

The programme has been offered to 10 different farms in the Christiana district to approximately 486 participants (Nieuwoudt 2013). Four hundred and eighty-six farm workers have already participated. In the nine years of its implementation in the Christiana district, it has been proven that the programme has made an impact and is still making inroads in alleviating family challenges.

\section{Introduction and problem statement}

In this article, the Biblical Fatherhood Training and Equipping Programme is proposed as a contribution to support and reinforce faith communities so that they can stop the social issue of father absence (Freeks 2011a, 2011b). Why is the Bible incorporated in a training programme? The Bible is approximately 2000 years old. Because of its antiquity, many authors, researchers, academics and even the general public question the applicability and relevance of the Bible's moral teachings to contemporary life. Even some Christians are not fully confident or assured of the importance and relevance of the Bible to the problems and issues of modern society such as father absence, fatherlessness, un-involvement of fathers and broken families.

The author, being the initiator of this study and a Christian, very clearly regards the Bible as a reliable, authoritative and trustworthy standard for morality and the mentioned issues. It is not because the Bible has been used as the source and foundation for human issues such as moral values with which many, including the author, were raised and which have dominated cultures, traditions and civilisation. Instead, it is because the author relies on the Bible as the standard and foundation for issues and morality because he is persuaded that biblical principles, ethical norms and moral teachings come from God the Father and the Bible is the Word of God. This author's argument may seem obvious and even irrelevant, but it is worth reflecting on its significance 
specifically in our walk and lived experience with God and the Bible, as well as our engagement and dealings within a secular world or context.

The Biblical Fatherhood Training and Equipping Programme has been used to train and equip faith-based communities in the Christiana district in the North West province who grapple with fatherhood matters. The view of fatherhood has changed tremendously over time and, according to research and academic studies, most families struggle with severe problems and challenges in society. A devastating problem and challenge is the father absence amidst dilemma, which is detrimental to society because of its increase within communities, which has brought an unforeseen and incredible social tendency, namely, the downturn of fatherhood (Popenoe 1996).

Father absence is a societal malice challenging the nation of South Africa (Salami \& Okeke 2018:2). Father absence is furthermore a serious concern, which Carstens (2014) identified in his research as the fourth-ranked problem of the world. Research consistently confirms that the notion of fatherhood and the issue of father absence are crucial matters in society (Freeks 2019:1-3; Londt, Kock \& John-Lanba 2017: 154-155; Matlakala et al. 2019:6-7; Salami \& Okeke 2018:4-7).

Research has also shown that a dysfunctional family life is a major societal problem, with father absence being the locus (Carstens 2014:10). Father absence is a tendency and world-wide phenomenon in many communities in the world (Freeks, Strydom \& Bartlett 2015:46; Dobbs 2013:2; Williams 2014). Statistically, there is a tendency akin to a 'fatherhood disease' globally and a rapid increase in single parenting (Freeks 2019:1-3; Goodsell \& Meldrum 2010; Statistics South Africa 2011). The fathers' absence is the ultimate cause for the rising incidence of single mothers in South Africa (Bertelsmann 2016). Single-parent households have become the norm in South Africa, where the 'typical' child is raised by only the mother. The number of children living without their fathers has increased unabatedly in the almost two decades of democracy in South Africa. The absence of father has been constructed as socially detrimental and a dilemma for most children in South Africa, as the lack of a father figure means the child has no positive male role model in the home. Father absence not only has a severe impact on family life but also is a worrying social trend second to major diseases such as human immunodeficiency virus (HIV) and acquired immune deficiency syndrome (AIDS) (Freeks 2019:2). The HIV epidemic is mentioned by Yi and Nel (2020:2) as one of the main reasons for father absence.

Furthermore, father absenteeism holds negative consequences for families and communities and many families experience a difficult family life because of these problems. When these problems are detrimental and devastating to families, family members may blame God for ills and misfortunes in their lives. Hence, the call for biblical fatherhood is needed and important for families, communities and parents. Children are a gift from God to parents, but numerous children have been raised in families where fathers have been neglecting their responsibilities (Freeks 2008). South African society has strayed from recognising the importance of fatherhood because of father absenteeism.

In addition, the trend of fathers being absent and not fulfilling their role is a serious challenge for fatherhood and the current fatherhood debate including the fatherhood dialogue does not look favourable either (Eddy, Thomson-de Boor \& Mphaka 2013:10). The latter in South Africa is associated with the idea of masculinity and based on the socio-economic history (Richter \& Morrell 2006). However, even if fatherhood is masculine, it has ample distinctive forms (Leopeng \& Langa 2017:438).

In the sociological context, fatherhood is regarded as socially constructed because family and fatherhood are not seen as entities but as social institutions (Thunsteadt 2017:4). Moreover, studies conducted in South Africa about fatherhood have focussed mainly on violence, gender power, masculine control, paternal maintenance and family provision (Ratele, Clowes \& Shefer 2012). Fatherhood goes beyond the themes of violence, gender and provision. In the author's opinion, the element of biblical or Christian fatherhood is very rare in certain research and some academic studies. $\mathrm{Yi}$ and $\mathrm{Nel}$ (2020:1), for example, mentioned in their studies that adolescent children who are distant or absent from their fathers have difficulty in sensing God the Father's closeness and they may also experience a negative concept of God.

\section{Research objective}

The research objective of this article is to discuss the fatherhood training and equipping programme and its biblical impact on farm workers (faith communities) in the Christiana District and to reflect on the spiritual life, lived experiences and growth of farm workers.

\section{Research design and methodology}

This article followed on from a reflective discussion where training and equipping were conducted through a community engagement strategy based on a practical theological research on biblical fatherhood (cf. Freeks 2011a). The discussion evolved through research, theory, training, equipping and reflection. Reflection as a methodology enables researchers and practitioners to theorise from their own practice, improving and developing their work (Morley 2013:166). Reflection is a very significant mental activity. It is also a turning back onto 'a self' where the researcher (inquirer) is an observer (Mortari 2015:1). The context of the reflective discussion was the Christiana District and its participants, the farm workers, also referred to as the faith communities, and this approach aimed especially to reflect on farm workers' lived experiences, behaviour, spiritual life and the idea of the Bible with regard to the fatherhood programme. 


\section{The concept of fatherhood}

The fatherhood concept is the main emphasis in the programme. Fatherhood from a biblical perspective is what the programme is all about. The notion around fatherhood, parenthood and family life is shifting greatly as people find themselves caught between traditional and contemporary understandings of fatherhood (Richter, Chikovore \& Makusha 2010:2). In South Africa, the fatherhood concept is generally related to manhood or masculinity (Meyer 2018:4; Morrell 2006:15), which is a human and cultural role (Richter \& Morrell 2006:8, 18).

There is, for example, the traditional manner in which the emphasis is placed on the biological aspects and the modern time concept where the emphasis is on two dimensions, namely, the economic and social dimensions (Morrell 2006:14). However, fatherhood cannot be understood outside the paradigm of patriarchy (Meyer 2018:7) because fatherhood is more than the concept of patriarchal fatherhood. Authors like Dowd (2012:917-919) said that fatherhood should be defined as the manner of caring for children, which relates to the physical, emotional, intellectual and spiritual care.

Other authors stated that fatherhood alludes to the paradigm that certain men are granted the role of being a father and have responsibilities for children (McCarthy \& Edwards 2011:95). Fatherhood can also be defined as the attending to the needs of children by providing spiritual and physical care and attending to intellectual and emotional matters (Dowd 2012:917-919; Freeks 2019: 692-696; Makofane 2015:24). The concept of fatherhood can be understood and lived out in many ways. There is no agreed-upon concept or definition of fatherhood and researchers and academics understand the concept differently (Rabe 2006:25).

With the exception of the above-mentioned, other research consistently confirms that fatherhood is essential in society and fathers still play an important role within the family (Vaughan 2010). Abraham Lincoln confirmed the importance of fatherhood over two centuries ago in his statement that the strength of a nation is found in the home where the father and the mother function together (Family Life 1998:2).

The most profound shift in understanding fatherhood will come from knowing God as Father (Smail 1980:10).

Fatherhood originates in the Fatherhood of God. He is the Father of his creation and his people, and the attributes of his Fatherhood should be perceived as protection, provision, warmth, gentleness, forgiveness, and involvement so that human parenting can adopt and flow from this concept. The biblical analogy comparing the human father and Father God suggests a view of human fatherhood that requires the man to adjust to biblical fatherhood.
Over the last few decades, fathers have become an increasing presence in research, but there is still much to learn and discover about fathers and their roles. Most studies (including Cabrera 2020; Meyer 2018; Pekel-Uludagli 2019; Peyper, De Klerk \& Spies 2015; Sieber 2008; Wood \& Brownhill 2018) consider father involvement, father attachments and fatherhood models from the psychological, social and physical sciences with the human father at the centre. Few studies show the meaningful effect from the Fatherhood of God. One significant study from the second perspective is that of Popenoe (1996).

The author's initial argument in terms of the concept and definition is that fatherhood stems from the Bible and this is key to comprehending the concept from a biblical perspective. Fatherhood is also about the role of the father in the family with particular viewpoints such as responsibilities, accountabilities, respect, discipline and obedience. Family in this context is God's structure in society to restore brokenness within a community.

According to Nel (2018:56), we learn about the emphasis of a family in Genesis 17 where God is dealing with households. $\mathrm{Nel}$ also indicated that the Bible is the book of family stories. God as the Trinity is a divine family and the family unit as a trinity of father, mother and children is a representation of that divine community. Our world is in need of a perfect Heavenly Father. But the notion of fatherhood has changed over time and as a result, most families are battling with serious issues and challenges in their respective communities.

One of the serious issues in family life currently is precisely the fatherhood problem. The concept of fatherhood is as old as Christianity itself but not limited to the Christian religion (Meyer 2018:1). This simply means that the solution to fatherhood concerns, such as father absenteeism, fatherlessness and father hunger, lies in God through his Son Jesus Christ with the guidance of the Holy Spirit. The biblical fatherhood notion is not exclusive to an authoritative source of admonition, connection, teaching, training and equipping. It instead provides significant measures and guidelines that corroborate to the uniqueness of God as Father whilst underlining the value of an earthly father within a family system.

The author is strongly of the opinion that this biblical way of expressing fatherhood has, however, declined and died out. This biblical way should be reinstated. The revelation of God through Scripture as the Father through his son Jesus Christ and his saving grace provides not only knowledge but also basic help, advice and meaningful insight into fatherhood in an era of broken families and father absence. The earthly father should fulfil this biblical role because he is called by God to do this in the context of the family.

In addition, the biblical analogy comparing the human father and God the Father suggests a view of human fatherhood that requires the man to adjust to biblical fatherhood. 
The father should fulfil his role of a figure of authority and is called upon by God to fulfil this role and calling in the context of the family, especially the children.

\section{The Biblical Fatherhood Training and Equipping Programme Origin and background}

The Biblical Fatherhood Training and Equipping Programme was first drafted in 2011 (cf. Freeks 2011b), structured and compiled from my own research (cf. Freeks 2004, 2011b). It was later extended, amended and adapted from further studies in fatherhood, father absenteeism, uninvolved fathers and the fundamental role of the father within the family context (Freeks 2018). The Biblical Fatherhood Programme officially started in 2012 in the Christiana District, North West province. The programme is also part of the Community Engagement Projects of the Faculty of Theology, in Potchefstroom. The programme has the potential to positively impact faith communities and to influence them against the negative aspect of father absence positively.

\section{The layout of the Biblical Fatherhood Training and Equipping Programme}

The layout of the programme consists of a manual, workbook and practical activities (cf. Freeks 2011b). The themes of the Biblical Fatherhood Training and Equipping Programme are:

- the concept of fathering

- the importance of self-image

- the idea of character and career

- the facet of labelling

- the facet of disappointments

- the father as developer and

- the father fulfilling his role within the family.

\section{The aims of the Biblical Fatherhood Training and Equipping Programme}

The Biblical Fatherhood Training and Equipping Programme addresses father absenteeism, un-involvement and family issues. The programme also aims to build better relationships in families through the leadership of the father and mother by addressing the fundamental role of the father within a family context. Farm workers (fathers) are encouraged to get more involved in the lives of their families, especially their children. The programme further strives to enable farm workers to connect with each other, feel empowered and help identify common purposes amongst them. In addition, the content strongly emphasises the Biblical truths about fatherhood and is used to guide, train and equip farm workers with skills and biblical knowledge about the importance of fatherhood. The programme contains unique opportunities to make an eternal investment in the lives of faith communities by presenting Biblical answers and hope. Faith communities can once again flourish within society by building upon the foundation of trust, mutual respect, connection and engagement from a Biblical approach.

\section{The impact of the Biblical Fatherhood Training and Equipping Programme with farm workers (faith communities)}

It was important for the researcher to reflect on seven specific and crucial observations after farm workers were trained and equipped with the Biblical Fatherhood Training and Equipping Programme.

\section{Observation 1: The value of the Biblical Fatherhood Training and Equipping Programme}

Farm workers (faith communities) indicated that they had a life-changing experience through the Biblical Fatherhood Training and Equipping Programme. The reason was that the programme helped them return to God and their lives changed for the best. Significantly, over $50 \%$ of the farm workers indicated a high interest in Christianity. Most farm workers evaluated the programme as extremely high. Participants mentioned the following: 'The programme taught us to invite God into our problems.' During the training and equipping, the researcher noticed that most of the farm workers had a distorted view of themselves, which led to a distorted view of how God sees and looks at them. Hence, the programme has the potential to instruct farm workers about God and strengthen them to make quality decisions about their lives, especially when faced with critical decisions. The programme taught a large number of farm workers about the significance of prayer, especially when faced with life issues. It was paramount during the training that farm workers understood that they should spend time in prayer before God, especially when grappling with challenges and difficult circumstances (cf. Jakes 2008:434). Some participants pointed out that something had been missing in their lives and therefore, they made the fatherhood programme a part of their lives. The programme taught them that they could become specialists in their work fields because no individual is insignificant and every person is valuable in life, especially in the eyes of God.

\section{Observation 2: The role of the Biblical Fatherhood Training and Equipping Programme}

Through the programme, the researcher made it very clear to participants that God has a unique and central role in the Biblical Fatherhood Training and Equipping Programme. They indicated the following: 'The fatherhood programme brought us back to God and helped us realise how important God and life is.'

Humans are God's creations and are therefore potentially good people made in the image of God. Believers live in relationship with God, themselves, others and the world around them (cf. Freeks 2008). Furthermore, it is paramount to know that all life started with God and life finds its purpose in God (cf. Col 1:16). God is most important in human life because humans were made by God and for God's pleasure. Until humans understand this, life itself will not make sense to them (Van der Walt 1999:328-329; Warren 2002:17-18). 


\section{Observation 3: The Biblical fatherhood programme correlates with the Bible}

Because the fatherhood programme correlated with the Bible, farm workers stated that the programme provided important and relevant information, which is also what the Bible intends to do. Farm workers said the following: 'The programme increased our trust in God because it taught us about the Bible.' The Bible is the book of faith and the primary message is the kingdom of God. The Bible provides a key narrative of God's deeds in the history of humanity and all of creation (cf. Van der Walt 2001:68). The essence of the fatherhood manual is that it includes biblical principles in the programme. It taught numerous farm workers that they are special and unique individuals who are loved and appreciated by God and should look at themselves in the way God created them, not through their own eyes or through the eyes of others (cf. Freeks 2008). In addition, the course provided participants with biblical knowledge and strengthened their faith because farm workers were taught that the Bible as the Word of God is dynamic. This is because the communication and meaning of the Bible buds, grows, develops and ultimately yields to a harvest in people's lives (Jakes 2008:186). Almost all participants said that the Bible changed their lives because the fatherhood programme directed them to the Bible with answers and solutions to their problems and situations. The programme transformed numerous farm workers' lives for the better because it was taught from a biblical viewpoint (Freeks 2008). In the Scriptures, Paul teaches that humans' lives are changed through Jesus Christ (Phlp 3:21). Van der Walt (2008:15) shed more light on this by indicating that the Bible is God's written revelation where God reveals to humans the meaning of phenomena, which would otherwise remain unknown. Attachment to God predicts psychological well-being, especially when religious activities are involved, which helps a person cope with life experiences (Limke \& Mayfield 2011:123). It also became evident that farm workers started to believe in God and to rely on Him for their daily needs because of the programme. Significantly, God's Word teaches that people who believe in God will stand firm and succeed in life (2 Chr 20:20).

\section{Observation 4: The Biblical Fatherhood Training and Equipping Programme teaches that a healthy relationship with God is fundamental}

Farm workers indicated the following about the programme: 'The programme helped us experience healthy relations with God.' Farm workers can know the true meaning of their existence by understanding who they are in relation to God's creation of mankind (cf. Gn 1-2). Through spirituality, farm workers began to enjoy a healthy relationship with God. All Christians, including the farm workers, should have a personal relationship with God through Christ (cf. Munroe 2001:57).

\section{Observation 5: The Biblical Fatherhood Training and Equipping Programme should be brought into practice}

Most of the farm workers mentioned the following: 'The programme should be applied in our daily lives because it provided us with valuable knowledge about the Bible.' It is, therefore, their responsibility to put the knowledge into practice and apply what they have learnt from the programme.

\section{Observation 6: The importance of respect and self-respect in the Biblical Fatherhood Training and Equipping Programme}

The Biblical Fatherhood Training and Equipping Programme teaches respect for God, oneself, family members and others. Farm workers mentioned the following: 'Respect for God is foremost in our lives and that a lack of respect damages relationships and co-operation with one another.' The farm workers also pointed out the following: 'This attitude often results in bad conduct and behaviour amongst us as workers, which also influences our relationship with God.' The Bible has a moral facet that lays out the foundation of respect for God. Isaiah 17:7 commands that people should first pay respect to their Creator, the Holy One of Israel. People should honour and respect God and He will in turn honour and respect them (1 Sm 2:30).

In the New Testament, Jesus confirmed: If people honour and respect the Son, they honour and respect the Father (Jn 5:23). When people obey and respect God's guidelines, laws or ordinances, they enjoy a blessed and fulfilling life (Van der Walt 2010:25, 183).

Most farm workers stressed the importance of self-respect, respect for family members and the love for one another. They explained that respect and self-respect determine and influence one's entire life. Respect fosters reciprocal respect and farm workers should respect themselves first and make an effort to earn the respect of others (Oosthuizen 2006:5). Self-respect and family are vital because respect is an implicit 'rule' for close relationships such as families. Regarding love, the biblical testimony stresses that farm workers' lives should be controlled by love because Christ loved them and He gave his life for them as a sweet-smelling offering and a sacrifice that pleased God (cf. Hendrick \& Hendrick 2006:883; cf. also Eph 5:2 \& Jn 3).

Farm workers also commented the following:

'It is essential to treat others with respect. The programme strongly emphasises how to respect other people and how one can build one's self-image and the self-image of others by showing respect, an important aspect of interpersonal relationships and personal self-identity.'

The reason is that this is an emotion-based concept, which has been considered an important aspect of individual identity over the past few decades. Respect is an especially important facet in a marriage (Hendrick \& Hendrick 2006:882). Couples have two basic needs in their marriage, namely, love and mutual respect. Respect for others is a concept that is highly recommended by biblical testimony (Frei \& Shaver 2002:121; cf. Rm 12:9). 
Observation 7: The Biblical Fatherhood Training and Equipping Programme teaches important knowledge, self-knowledge, thankfulness and positive attitude

The farm workers indicated the following about the programme: 'The programme helped us gain extensive knowledge, and developed an appreciation and positive outlook towards life.' In terms of self-knowledge, farm workers mentioned that they were fully aware of who they are after the fatherhood programme.

Participants also mentioned the following: 'We know what our relationships should be like and how to take care of ourselves.' Emotionally literate farm workers can also get along with other people. They will, therefore, resolve conflicts, motivate themselves and even achieve most of their goals in life (cf. Rae, Nelson \& Pederson 2005:18). Most people in life struggle with the question 'who am I?' and their purpose in life (Warren 2002:312). To know one's purpose will simplify one's life because your purpose defines what you choose to strive for. A purpose becomes the standard a person can use to assess which aspects in life are essential and those that are not (Warren 2002:31). When individuals are honest and open, their personality will reflect their true self, which is the essence of who someone really is and how such a person genuinely behaves. It should be remembered that one's true self gives meaning in life (Schlegel et al. 2011:1-2). The reason is that the true self comprises the characteristics and attributes that define who the person genuinely is (Schlegel \& Hicks 2011:991). People's true selves are essentially God's gift to them; what they do with themselves is their gift to God (Warren 2002:249).

According to the biblical testimony, humankind is created in the image of God and is functioning parts in Christ's body (Gn 2:26-27; Rm 12:5). The Biblical Fatherhood Training and Equipping Programme teaches farm workers not only to mature and grow in secular knowledge or self-knowledge but also in the knowledge of the Bible. Through Jesus Christ, people can grow in grace and knowledge and discover who they are and what their purpose entails (2 Pt 3:18). God's goal for farm workers is to mature, grow spiritually and develop the characteristics of Jesus Christ. His purpose prevails, despite people's numerous plans and life designs (Eph 4:15; Pr 19:21; Warren 2002:179).

Regarding thankfulness, farm workers alluded to the following about the programme:

\footnotetext{
'The programme taught us how to be thankful and appreciate life, which has improved us as individuals', and 'We felt grateful for the programme and that it is an education tool toward success'.
}

Joyful and pleasant emotions are aspects of a thankful person and gratitude is the foundation to a person's wellbeing (Ahrens \& Forbes 2014:342; Smith, Tong \& Ellsworth 2014:19). Most people wish to experience happiness instead of unhappiness and they value positive emotions such as enthusiasm and excitement (cf. Livingstone \& Srivastava 2014:84). It should also be remembered that thankfulness produces sound health (Battié 2015:557). According to biblical teaching, God expects people (farm workers in this context) to be thankful in all life circumstances (1 Th 5:18). The Bible said in Ephesians 5:20 that believers should give thanks to God the Father for everything.

In terms of the evaluation of life-changing and a positive attitude towards life, farm workers clarified the following:

'Our lives changed for the better and we felt highly positive toward life'.

'We accepted ourselves and we are not waiting for someone to change our lives' and

'We felt positive toward life, and we will not be giving up because we had gained a clear vision for life after attending the programme'.

Of the utmost importance is that participants should understand that a positive attitude and personality lead to healthier outcomes (cf. Kato et al. 2012:359).

This understanding explains one of the important modules in the Biblical Fatherhood Training and Equipping Programme. Farm workers will likely give up if they have a negative attitude because of incidents they live through, because they would be focusing on the negative instead of the positive and constructive viewpoint (O'Baugh et al. 2008:111). In addition to the negative attitude, if people do not have a vision, according to biblical wisdom, they will not fulfil their purpose (Pr 29:18). Therefore, it is vital to have a vision and a purpose in life. This is exactly what the Biblical Fatherhood Training and Equipping Programme entails.

\section{Recommendations}

This article about farm workers (faith communities) and the Biblical Fatherhood Training and Equipping Programme in the Christiana District led to these recommendations:

- It is crucial to first get approval to access farm communities before any project, program, intervention, workshop or research can be conducted on farms in the North West province.

- Proper fatherhood knowledge and skills training should be submerged in the content of the Biblical Fatherhood Training and Equipping Programme, in order to train and equip farm workers for their essential role of being members of faith communities in society.

- Biblical aspects and truths are the motivating impact and strength behind the programme and are gaining attention in this article; hence, this programme should be rolled out to other farming communities in the province and the country.

- Faith communities should be encouraged to build strong and steadfast families and train effective parenting. 


\section{Conclusion}

The core aspect of the Biblical Fatherhood Training and Equipping Programme teaches farm workers (faith communities) to be effective parents, involved in their own families, especially teaching them from the Bible about God as Father. This is a major challenge for farm workers because many are sometimes intimidated and the popular views of community members even challenge their role. Human fatherhood should be taken seriously because it is anticipation of what and who God the Father is; if human fatherhood does not exist, then all truth and knowledge about God the Father is void and insignificant. Fatherhood today is an element and perhaps the most threatened element in the world. This is why faith communities have a crucial and relevant responsibility regarding fatherhood.

\section{Acknowledgements Competing interests}

The author declares that they have no financial or personal relationships that may have inappropriately influenced them in writing this article.

\section{Author's contribution}

F.E.F. is the sole author of this research article.

\section{Funding information}

This research received no specific grant from any funding agency in the public, commercial or not-for-profit sectors.

\section{Ethical considerations}

This article followed all ethical standards for research without direct contact with human or animal subjects.

\section{Data availability}

Data sharing is not applicable to this article as no new data were created or analysed in this study.

\section{Disclaimer}

The views and opinions expressed in this article are those of the author and do not necessarily reflect the official policy or position of any affiliated agency of the author.

\section{References}

Ahrens, A.H. \& Forbes, C.N., 2014, 'Gratitude', in M.M. Tugade, M.N. Shiota \& L.D. Kirby (eds.), Handbook of positive emotions, pp. 342-361, Guilford Press, New York, NY.

Baldwin, I. \& Poje, A.B., 2020, 'Rural faith community leaders and mental health center staff: Identifying opportunities for communication and cooperation', Journal of Rural Mental Health 44(1), 16-25. https://doi.org/10.1037/rmh0000126

Battié, R.N., 2015, 'Thriving with thankfulness', AORN Journal 102(6), 557-558. https://doi.org/10.1016/j.aorn.2015.10.012

Bertelsmann, M., 2016, Where have our fathers gone?, viewed 10 January 2021 from http://www. parent24.com/Family/Parenting/where-have-our-fathersgone-20160217-2.

Cabrera, N., 2020, 'Father involvement, father-child relationship, and attachment in the early years', Attachment and Human Development 22(1), 134-138. https:// doi.org/10.1080/14616734.2019.1589070
Carstens, C., 2014, The world needs a father: A trainer's guide, Paarl Media Printers, Cape Town.

Chifeche, V. \& Dreyer, Y., 2019, 'Faith communities, youth and development in Mozambique', HTS Teologiese Studies/Theological Studies 75(4), a5450. https:// doi.org/10.4102/hts.v75i4.5450

Dobbs, P., 2013, 'The impact of fatherlessness on the way one relates to God as Father', MTh dissertation, University of Otago, Dunedin, viewed 04 March 2021 from http://hdl.handle.net/10523/4672.

Dowd, N.E., 2012, 'Fatherhood and equality: Reconfiguring masculinities', Psychology 42(4), 553-563. http://scholarship.law.ufl.edu/facultypub/401

Eddy, M.M., Thomson-de Boor, H. \& Mphaka, K., 2013, So we are ATM fathers: A study of absent fathers in Johannesburg, South Africa, Centre for Social Development in Africa, University of Johannesburg and Sonke Gender Justice, Johannesburg, viewed 04 March 2021, from https://genderjustice.org.za/publication/so-we-are-atm-fathers/.

Family Life, 1998, A declaration of timeless values, in Family Life, viewed 26 May 2017, from https://familylife.org.za/about-us/manifesto/.

Freeks, F.E., 2004, 'Die rol van die ontbrekende vaderfiguur in die Suid-Afrikaanse konteks: 'n prakties-teologiese studie', MA dissertation, North-West University.

Freeks, F.E., 2008, Manual for course facilitators: LIFEPLAN ${ }^{\circledR}$, Africa Unit for Transdisciplinary Health Research, North-West University, Potchefstroom.

Freeks, F.E., 2011a, 'The role of the father as mentor in the transmission of values: A pastoral-theological study', PhD thesis, North-West University.

Freeks, F.E., 2011b, Fatherhood training and equipping manual for fathers: Dad becoming fully you, Ivyline Technologies, Potchefstroom.

Freeks, F.E., 2018, 'Views of mothers on the fundamental role of the Christian father as mentor in a nuclear family environment', In die Skriflig 52(1), a2365. https:// doi.org/10.4102/ids.v52i1.2365

Freeks, F.E., 2019, 'Die probleem van vaderafwesigheid in Suid-Afrika vanuit Bybelse riglyne' [The problem of father absenteeism in South Africa from Biblical guidelines], Tydskrif vir Geesteswetenskappe 59(4), 1-16. https://doi. org/10.17159/2224-7912/2019/v59n4a17

Freeks, F.E., Strydom, C. \& Bartlett, E., 2015, 'Die impak van afwesige vaders op adolessente dogters se psigososiale welstand' [The impact of absent fathers on the psychological wellbeing of adolescent daughters], Health SA Gesondheid 20(1), 45-89. https://doi.org/10.1016/j.hsag.2015.03.002

Frei, J.R. \& Shaver, P.R., 2002, 'Respect in close relationships: Prototype definition, self-report assessment and initial correlates', Personal Relationships 9(2), 121-139. https://doi.org/10.1111/1475-6811.00008

Goodsell, T.L. \& Meldrum, J.T., 2010, 'Nurturing fathers: A qualitative examination of child-father attachment', Early Child Development 180(1-2), 249-262.

Hardison-Moody, A. \& Yao, J., 2019, 'Faithful families, thriving: Bridging faith and health through a state-level partnership', American Journal of Public Health 109(3), 363-369. https://doi.org/10.2105/AJPH.2018.304869

Hendrick, S.S. \& Hendrick, C., 2006, 'Measuring respect in close relationships', Journal of Social and Personal Relationships 23(6), 881-899.

Holland, B. \& Malone, M., 2019, 'Editorial. Institutional engagement - Intentional, innovative and rigorous', International Journal of Community Research and Engagement 12(2), 1-6. https://doi.org/10.5130/ijcre.v12i2.6984

Jakes, T.D., 2008, Life overflowing: Six pillars for abundant living, Bethany House, Minneapolis, MN.

Kato, K., Zweig, R., Barzilai, N. \& Atzmon, G., 2012, 'Positive attitude towards life and emotional expression as personality phenotypes for Centenarians', Ageing 4(5), 359-367.

Leopeng, B. \& Langa, M., 2017, 'The fathers of destiny: Representations of fatherhood in a popular South African magazine', Journal of Psychology in Africa 27(5), 438. https://doi.org/10.1080/14330237.2017.1379221

Limke, A. \& Mayfield, P.B., 2011, 'Attachment to God: Differentiating the contributions of fathers and mothers using the experiences in parental relationships scale', Journal of Psychology and Theology 39(12), 127-129.

Livingstone, K.M. \& Srivastava, S., 2014, 'Personality and positive emotion', in M.M. Tugade, M.N. Shiota \& L.D. Kirby (eds.), Handbook of positive emotions, pp. 82-99, Guilford Press, New York, NY.

Londt, M.P., Kock, M. \& John Langa, J., 2017, 'The effects of biological father's incarceration on adolescent children and the challenges of absentee biological fathers', Southern African Journal of Criminology 30(4), 145-158.

Makofane, M.D.M., 2015, “'Not all men are fathers": Experiences of African women from families with absent fathers', Social Work/Maatskaplike Werk 51(1), 24. https://doi.org/10.15270/51-1-426

Mashau, T.D., 2019, 'Foreigners go home! Re-imagining ubuntology and the agency of faith communities in addressing the migration crisis in the City of Tshwane', HTS Teologiese Studies/Theological Studies 75(4), a5595. https://doi.org/10.4102/hts.v75i4.5595

Matlakala, F.K., Makhubele, J.C., Sekgale, I.L. \& Mafa, P., 2019, 'Perspectives of single mothers on the socio-emotional and economic influence of "absent fathers" in a child's life: A case study of rural community in South Africa', Journal of Social Sciences and Humanities 16(4), 1-12.

McCarthy, J.N. \& Edwards, R., 2011, Key concepts in family studies, Sage, London.

Meyer, J., 2018, 'Restructuring the Christian Fatherhood Model: A practical theological investigation into the "male problematic" of father absence', HTS Teologiese Studies/Theological Studies 74(1), 4870. https://doi.org/10.4102/hts.v74i1.4870

Moon, Z., 2019, "Turn now, my vindication is at stake": Military moral injury and communities of faith', Pastoral Psychology 68(4), 93-105. https://doi. org/10.1007/s11089-017-0795-8 
Morley, C., 2013, 'Some methodological and ethical tensions in using critical reflection as a research methodology', in J. Fook \& F. Gardiner (eds.), Critical reflection in context: Applications in health and social care, pp. 166-178, Routledge New York, NY, viewed 12 January 2021 from https://www.researchgate.net/ publication/268210467_Some_methodological_and_ethical tensions_in_using critical reflection as_a_research methodology.

Morrell, R., 2006, 'Fathers, fatherhood and masculinity in South Africa', in L. Richter \& R. Morrell (eds.), Baba: Men and fatherhood in South Africa, pp. 8 \& 18, HSRC Press, Cape Town.

Mortari, L., 2015, 'Reflectivity in research practice: An overview of differen perspectives, International Journal Qualitative Methods 14(5), 1-9. https://doi. org/10.1177/1609406915618045

Munroe, M., 2001, Understanding the purpose and power of men: A book for men and the women who love them, Whitaker House, New Kensington, PA.

Nel, M., 2018, Youth Ministries: An inclusive missional approach, HTS Religion \& Society Series, vol. 1, AOSIS, Cape Town.

Nieuwoudt, M., 2013, email, 20 November, marinda.wvmoere@gmail.com.

O'Baugh, J.O., Wilkes, L.M., Luke, S. \& George, A., 2008, 'Positive attitude in cancer: The nurse's perspective', International journal of nursing practice 14(2), 109-114. https://doi.org/10.1111/j.1440-172X.2008.00673.x

Oliker, D.M., 2011, 'The importance of fathers', Psychology Today, viewed 09 May 2020, from https://www.psychologytoday.com/za/blog/the-long-reachchildhood/201106/the-importance-fathers.

Oosthuizen, I.J., 2006, Praktiese wenke vir leerderdissipline, Van Schaik, Pretoria.

Pekel-Uludagli, N., 2019, 'Are uninvolved fathers really incompetent and unsatisfied? Testing the mediator role of the father involvement from fathers' perspectives', European Journal of Development Psychology 16(5), 538-551. https://doi.org/10. $1080 / 17405629.2018 .1472077$

Peyper, E., De Klerk, W. \& Spies, R., 2015, 'Experiences of young adult women with emotionally absent fathers', Journal of Psychology in Africa 25(2), 127-133. https//doi.org/10.1080/14330237.2015.1021513

Polat, S. \& Yildiz, H.O.T., 2019, 'Community engagement in developing urban design guidance for heritage sites: The case of Bursa, Turkey', Word and World 34(3), Summer, 294-305.

Popenoe, D., 1996, 'A world without fathers', Wilson Quarterly 20(2), 12-16.

Rabe, M., 2006, 'Being a father in a man's world: The experiences of goldmine workers', in L. Richter \& R. Morrell (eds.), Baba: Men and fatherhood in South Africa, p. 25, HSRC Press, Cape Town

Rae, T., Nelson, L. \& Pederson, L., 2005, Developing emotional literacy with teenage girls: Building confidence, self-esteem and self-respect, Sage, London.

Ratele, K., Shefer, T. \& Clowes, L., 2012, 'Talking South African fathers: A critical examination of men's contributions and experiences of fatherhood and fatherlessness', South African Journal of Psychology 42(4), 553-563. https://doi. org/10.1177/008124631204200409

Richter, L., Chikovore, J. \& Makusha, T., 2010, 'The status of fatherhood and fathering in South Africa', Childhood Education 86(6), 360-365.

Richter, L. \& Morrell, R., 2006, Baba: Men and fatherhood in South Africa, Human Sciences Research Council Press, Cape Town.

Salami, I.A. \& Okeke, C.I.O., 2018, 'Absent fathers' socio-economic status and perceptions of fatherhood as related to developmental challenges faced by children in South Africa', South African Journal of Childhood Education 8(1), 1-7. https://doi.org/10.4102/sajce.V8i1.522
Schlegel, R.J. \& Hicks, J.A., 2011, 'The true self and psychological health: Emerging evidence and future directions', Social and Personality Compass 5(12), 989-1003. https://doi.org/10.1111/j.1751-9004.2011.00401.x

Schlegel, R.J., Hicks, J.A., King, L.A. \& Arndt, J., 2011, 'Feeling like you know who you are: Perceived true self-knowledge and meaning in life', Personality and Socia Psychology Bulletin 20(10), 1-12.

Sieber, D., 2008, 'Engaging absent fathers in the treatment of children', Clinical Socia Work 36(4), 333-340. https://doi.org/10.1007/s10615-008-0158-0

Smail, T.A., 1980, The forgotten father: Rediscovering the heart of the Christian Gospel, SCM Press, Sydney.

Smith, C.A., Tong, E.M.W. \& Ellsworth, P.C., 2014, 'The differentiation of positive emotional experience as viewed through the lens of appraisal theory', in M.M. Tugade, M.N. Shiota \& L.D. Kirby (eds.), Handbook of positive emotions, pp. 11-27, Guilford Press, New York, NY.

Statistics South Africa, 2011, General household survey 2010, Statistical release PO318, June 2010, viewed 10 January 2021, from http://www.statssa.gov.za/ publications/P0318/P03182018.pdf.

Thunsteadt, C., 2017, Masculinities and fatherhood in parenting discourses: an ethnographic content analysis of Polish childcare magazines for fathers, viewed 05 March 2021, from https://su.divaportal.org/smash/get/diva2 1117048/FULLTEXT01.pdf.

Van der Walt, B.J., 1999, 'Visie op die werklikheid, die bevrydende krag van 'n Christelike lewensbeskouing en filosofie', PhD thesis, North-West University.

Van der Walt, B.J., 2001, Transformed by the renewing of your mind: Shaping a biblical worldview and a Christian perspective on scholarship, The Institute for Contemporary Christianity in Africa, Potchefstroom.

Van der Walt, B.J., 2008, The eye is the lamp of the body: Worldviews and their impact, The Institute for Contemporary Christianity in Africa, Potchefstroom.

Van der Walt, B.J., 2010, At home in God's word: A transforming paradigm for being human and for social involvement, The Institute for Contemporary Christianity in Africa, Potchefstroom.

Vaughan, J., 2010, 'Dads and the daughters they love', in Focus on the family, viewed 26 May 2019, from http://www.focusonthefamily.ca/parenting/fatherhood/dadsand-the-daughters-they-love.

Warren, R., 2002, The purpose driven life: What on earth am I here for?, Zondervan, Grand Rapids, MI.

Wikipedia, n.d., Christiana, North West, viewed 20 November 2013, from https:// en.wikipedia.org/wiki/Christiana,_North_West.

Williams, R.B., 2014, 'The decline of fatherhood and the male identity crisis', Psychology Today, viewed 26 May 2020, from https://raywilliams.ca/the-declineof-fatherhood-and-male-identity-crisis/.

Wood, P. \& Brownhill, S., 2018, 'Absent fathers', and children's social and emotional learning: An exploration of the perceptions of "positive male role models" in the primary school sector', Gender and Education 30(2), 172-186. https://doi.org/10. 1080/09540253.2016.1187264

Wyngaard, J., 2015, 'Missio Dei and youth ministry: Mobilizing young people's assets and developing relationships', Missionalia 43(3), 410-423. https://doi. org/10.7832/43-3-120

Yi, H. \& Nel, M., 2020, 'Father absence and adolescents as a challenge to youth ministry', In die Skriflig 54(1), a2503. https://doi.org/10.4102/ids.v54i1.2503 